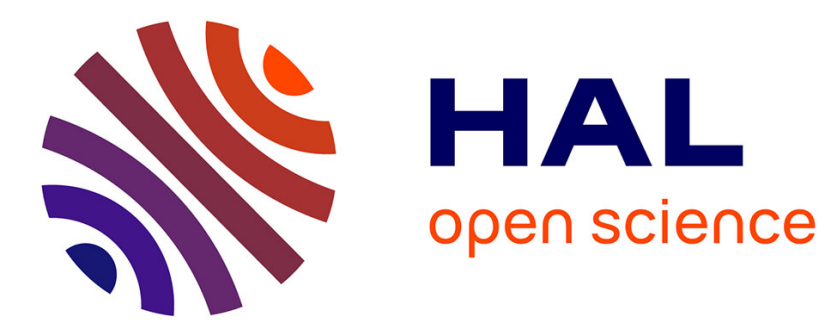

\title{
Coupling effect between magnetizations of 2 thin layers separated by a thin nonmagnetic metallic layer
}

Jean-Claude Bruyere, G. Clerc, Olivier Massenet, Robert Montmory, Louis

Néel, D. Paccard, A. Yelon

\section{- To cite this version:}

Jean-Claude Bruyere, G. Clerc, Olivier Massenet, Robert Montmory, Louis Néel, et al.. Coupling effect between magnetizations of 2 thin layers separated by a thin nonmagnetic metallic layer. Journal of Applied Physics, 1965, 36 (3 Partie 2), pp.944-945. 10.1063/1.1714271 . hal-02887453

\section{HAL Id: hal-02887453 \\ https://hal.science/hal-02887453}

Submitted on 2 Jul 2020

HAL is a multi-disciplinary open access archive for the deposit and dissemination of scientific research documents, whether they are published or not. The documents may come from teaching and research institutions in France or abroad, or from public or private research centers.
L'archive ouverte pluridisciplinaire HAL, est destinée au dépôt et à la diffusion de documents scientifiques de niveau recherche, publiés ou non, émanant des établissements d'enseignement et de recherche français ou étrangers, des laboratoires publics ou privés. 


\title{
Film Preparation
}

\author{
H. Lours, Chairman \\ Coupling Effect Between the Magnetizations of Two Thin Layers Separated by a
Thin Nonmagnetic Metallic Layer*
}

\author{
J. C. Bruymere, G. Clerc, O. Massener, R. Montmory, L. Néel, D. Paccard, and A. Yelon \\ Laboratoire d'Electrostatique et de Physique du Métal, Grenoble, France
}

\begin{abstract}
The coupling between films of $\mathrm{NiFe}$ and another ferromagnetic material separated by a thin layer of a nonferromagnetic metal has been investigated for the cases of $\mathrm{Au}, \mathrm{Ag}, \mathrm{Cr}$, and $\mathrm{Pd}$ intermediates. It is found that for Pd an alloy formation takes place during evaporation, and that for $\mathrm{Cr}$, a porosity effect is important. It appears unlikely that either of these effects can be important for $\mathrm{Au}$ and $\mathrm{Ag}$, and in these cases the possibility of indircet exchange must be considered seriously.
\end{abstract}

$\mathbf{W}^{\mathrm{s}}$ E have previously reported ${ }^{1-3}$ that two ferromagnetic films separated by a nonmagnetic metallic film may exhibit a coupling tending to align the magnetizations of the two magnetic layers parallel. Such a coupling has been observed between NiFe and $\mathrm{NiFeCo},{ }^{1,3}$ between $\mathrm{NiFe}$ and $\mathrm{NiFe},{ }^{4}$ between $\mathrm{NiFe}$ and $\mathrm{Co}$, and between $\mathrm{NiFe}$ and $\mathrm{FeCo}$. The intermediates employed in these experiments have generally been $\mathrm{Au}, \mathrm{Ag}, \mathrm{Cr}$, or $\mathrm{Pd}$, although coupling has also been observed for $\mathrm{Cu}, \mathrm{Al}$, and In intermediate layers. No such coupling has been observed for a series of insulators $60 \AA$ or more thick. ${ }^{2}$

The interaction energy observed may attain values of the order of $0.15 \mathrm{erg} / \mathrm{cm}^{2}$ for $50-\AA$ thicknesses of the intermediate metals, decreasing with increasing thickness. For all intermediates for which the NiFe$\mathrm{NiFeCo}$ coupling has been studied, $\mathrm{Au}, \mathrm{Ag}, \mathrm{Cr}$, and $\mathrm{Pd}$, the decrease is roughly linear with thicknesses. ${ }^{1}$ For these same intermediates, the coupling energy for $\mathrm{NiFe}$ and $\mathrm{Co}$ films decreases rapidly at first, and then more slowly. The variation of coupling energy for NiFe-Pe-NiFeCo is illustrated in Fig. 1. The variation for $\mathrm{NiFe}-\mathrm{Cr}-\mathrm{Co}$ and $\mathrm{NiFe}-\mathrm{Pd}-\mathrm{Co}$ is shown in Fig. 2.

For all films which we have studied with intermediate layers of $\mathrm{Cr}$, of $\mathrm{Ag}$, or of $\mathrm{Au}$, the coupling is virtually constant over the temperature range $77^{\circ}$ to $600^{\circ} \mathrm{K}$. When $\mathrm{Pd}$ is used as the intermediate, the interaction energy varies rapidly with temperature, as shown in Fig. 3. The form is the same for NiFe-Pd-Co, $\mathrm{NiFe}-\mathrm{Pd}-\mathrm{NiFeCo}$, or $\mathrm{NiFe}-\mathrm{Pd}-\mathrm{FeCo}$, and appears to depend uniquely upon the intermediate material.

A number of mechanisms which may produce such a coupling have been considered and rejected, ${ }^{1,2}$ and we have been lead to examine two possibilities for the

\footnotetext{
* Supported by DGRST Contract 62-FR-163 and by the CNRS. $1 \mathrm{~J}$. B. Bruyère, $O$. Massenet, R. Montmory, and L. Néel, Proc. Intermag. Conf. 1964, p. 16-1-1.

${ }^{2}$ J. C. Bruyère, O. Massenet, R. Montmory, and L. Néel, Compt. Rend. Acad. Sci. (France) 258, 841 (1964).

${ }^{3} \mathrm{~J}$. C. Bruyère, $O$. Massenet, R. Montmory, and L. Néel, Compt. Rend. Acad. Sci. (France) 258, 1423 (1964).

4 A. Yelon, O. Massenet, and R. Montmory, Proc. Phys. Soc. (London) (to be published).
}

origin of this effect in detail: diffusion, either massive or along porosities or grain boundaries; or an indirect exchange, such as has been discussed recently by Dreyfus et al. ${ }^{5}$ In a search for porosities, the coupling has been measured for a series of films with $\mathrm{Au}$ or $\mathrm{Cr}$ intermediates and the magnetic material has then been dissolved away with dilute nitric acid. Under electron microscopic examinations, $\mathrm{Cr}$ films between 50 and $300 \AA$ prepared at $350^{\circ}$ exhibit gaps at grain

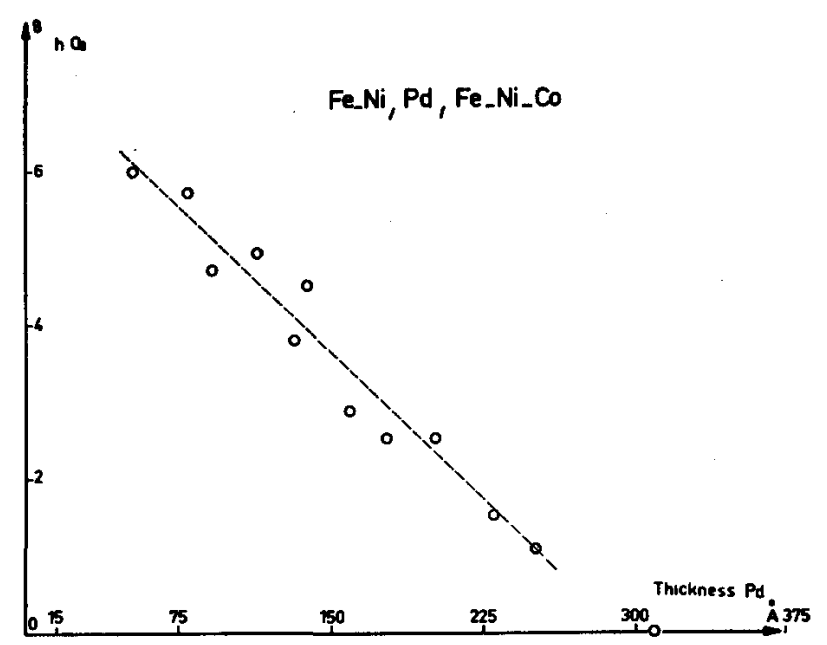

FIG. 1. Coupling field vs thickness of Pd for FeNi-Pd-FeNiCo films. The FeNi and FeNiCo films are both $1800 \AA$ thick. The coupling field is related to the coupling energy density by the expression $E=M h t$, where $M$ is the magnetization and $t$ is the thickness of the NiFe film.

boundaries. The coupling energy decreases with a decrease in the number of openings and disappears near the thickness for which the film becomes continuous. In this case, it appears that the interaction may be due to the lacunar structure of the intermediate.

By contrast, for Au films between 50 and $150 \AA$, evaporated onto supports heated between $100^{\circ}$ and $280^{\circ} \mathrm{C}$, all of which exhibit coupling, there are no observable holes. This of course, does not preclude

\footnotetext{
${ }^{5}$ B. Dreyfus, R. Maynard, and A. Quattropani, Phys. Rev. Letters 13, 3420 (1964).
} 
the possibility of openings of a diameter very much less than 15 or $20 \AA$. However, diffraction study of these films does not reveal any trace of any other material than Au.

Variation of the temperature of the support during evaporation between room temperature and $350^{\circ} \mathrm{C}$ does not affect the value of the coupling energy for films with $\mathrm{Au}$ or $\mathrm{Ag}$ intermediate layers, nor does annealing in this temperature range. For $\mathrm{Cr}$ intermediates, annealing in the same range does not affect the interaction, but the coupling is found to increase with increasing evaporation temperature. This agrees with the hypothesis of "hole" coupling, since the grain size increases with increasing substrate temperature. In the case of $\mathrm{Au}$ and $\mathrm{Ag}$, such a mechanism seems much less likely from the point of view of both the microscopy and temperature studies. Since the bulk diffusion of $\mathrm{Fe}, \mathrm{Ni}$, or $\mathrm{Co}$ into $\mathrm{Au}$ at the evaporation temperatures used is very slow, ${ }^{6}$ and is almost nonexistent in $\mathrm{Ag}^{7}{ }^{7}$ we must take the possibility of indirect exchange seriously in these cases.

In the case of films with $\mathrm{Pd}$ intermediates, the coupling increases with increasing evaporation temperature between room temperature and $350^{\circ} \mathrm{C}$. For example, for $\mathrm{NiFe}-\mathrm{Pd}-\mathrm{Co}$ films made at $300^{\circ} \mathrm{C}$, the interaction disappears at $350 \AA$ of $\mathrm{Pd}$, while for $350^{\circ} \mathrm{C}$ films, it is still measurable to $600 \AA$ of $\mathrm{Pd}$. The coupling may also be increased after an anneal at $350^{\circ} \mathrm{C}$. These results suggest that diffusion may play an important role in the coupling observed with Pd intermediates; a number of experimental results indicate that Co diffuses into the $\mathrm{Pd}$ rapidly compared with $\mathrm{Ni}$ or Fe. It is known that a small amount of any of these three metals in Pd will render the Pd ferromagnetic. ${ }^{8,9}$ It is possible in these conditions that there

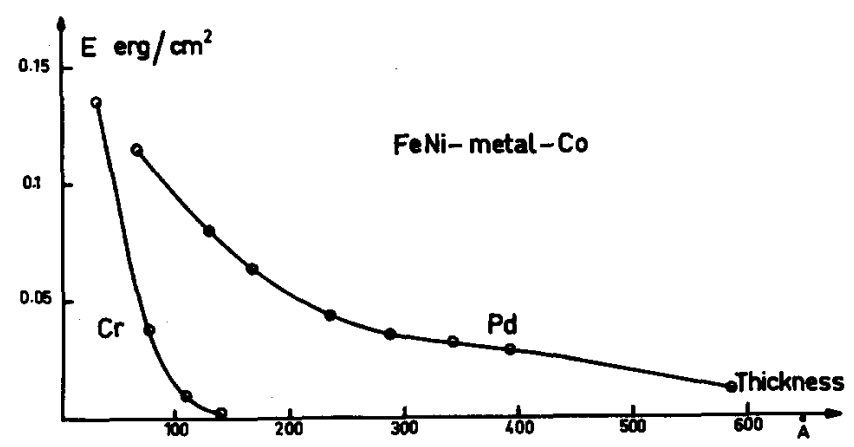

FIG. 2. Coupling energy vs thickness of intermediate layer for $\mathrm{NiFe}-\mathrm{Cr}-\mathrm{Co}$ and $\mathrm{NiFe}-\mathrm{Pd}-\mathrm{Co}$ films.

${ }^{6}$ D. Duhl, K. I. Hirano, and M. Cohen, Acta Met. 11, 1 (1963).

7 K. I. Hirano, M. Cohen, and B. L. Averbach, Acta Met. 11, 463 (1963).

${ }^{8}$ R. M. Bozorth, P. A. Wolff, D. D. Davis, V. B. Compton, and

J. H. Wernick, Phys. Rev. 122, 1157 (1961).

J. Crangle, Phil. Mag. 5, 335 (1960).

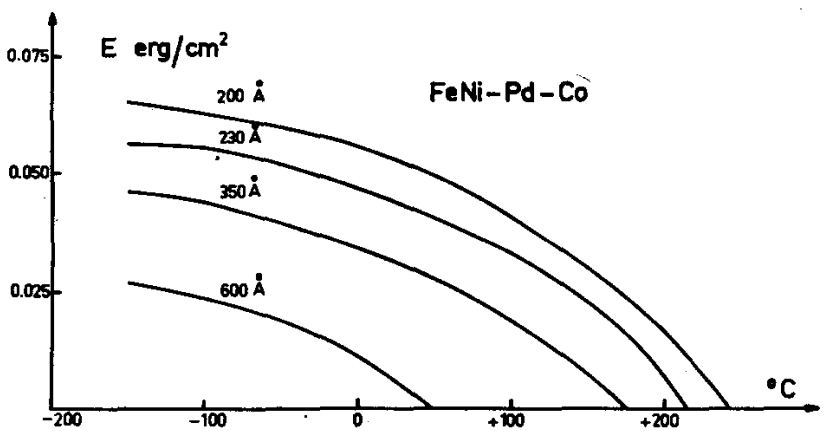

FIG. 3. Coupling energy vs. temperature for NiFe-Pd-Co films. The thicknesses given are those of the intermediate Pd layers.

exists a ferromagnetic liaison between the $\mathrm{NiFe}$ and the $\mathrm{Co}$, produced by a series of alloys primarily of $\mathrm{Pd}$ and $\mathrm{Co}$, with decreasing Co concentration as the distance from the Co layer increases.

The existence of Co diffusion in the Pd layer is demonstrated by measurements on films of $300 \AA$ of $\mathrm{Co}$ and of multilayers of $\mathrm{Co}-\mathrm{Pd}-\mathrm{Co}$, each Co layer $150 \AA$, separated by $1500 \AA$ of Pd, all evaporated at $350^{\circ} \mathrm{C}$, and not annealed. The magnetizations of the two samples were measured on a torque balance at room temperature and at nitrogen temperature. The change in the spontaneous magnetization of the $300-\AA$ Co film over this temperature range is less than $1 \%$. In contrast that of the Co-Pd-Co film, when cooled in a $300-O e$ field increases by $15 \%$, and is $10 \%$ greater than that for the pure $\mathrm{Co}$ at $77^{\circ} \mathrm{K}$. We attribute this to the formation of ferromagnetic $\mathrm{PdCo}$ alloys with Curie temperatures near or below room temperature.

The diffusion of Co in Pd appears well established, as does the effect of diffusion upon coupling energy, as this increases with increasing evaporation temperature and annealing. It is not yet clear, however, if the coupling in this case is due exclusively to ferromagnetic chains connecting the $\mathrm{Co}$ and the $\mathrm{NiFe}$, or whether the coupling may persist when there is a paramagnetic layer separating the ferromagnetic layers, that is, if there may also be an indirect coupling interaction, as has been proposed. ${ }^{5}$ We note that the shape of the curves of variation of coupling with temperature (Fig. 3) does not seem inconsistent with the first hypothesis, but it is not yet clear what form of variation is predicted by the indirect exchange theory in the particular case of Pd.

Thus, it appears that depending upon the intermediate material employed we must consider the possibility of at least three different mechanisms of indirect coupling: diffusion through holes, bulk diffusion, and indirect exchange. 